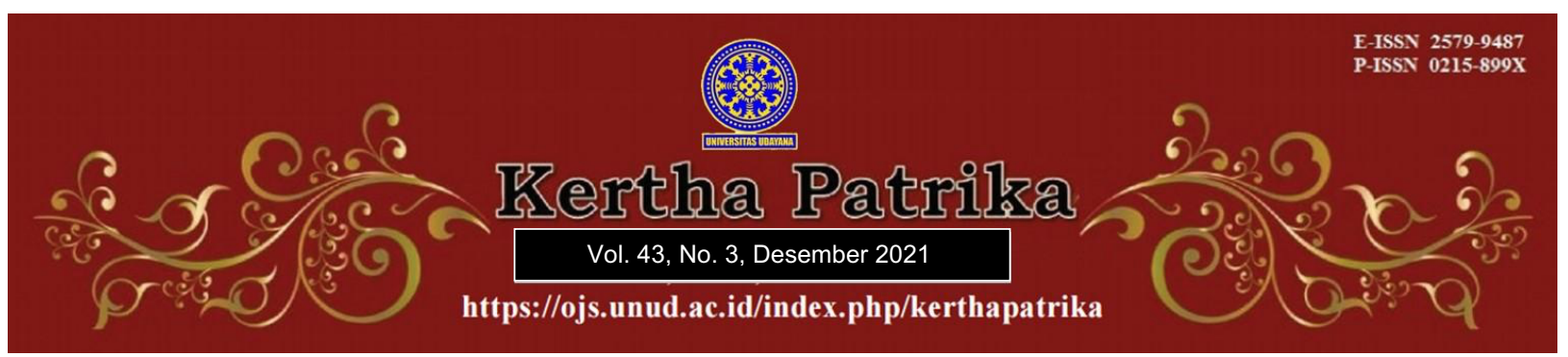

\title{
Konstitusionalitas Politik Kekeluargaan Dalam Pilkada Serentak
}

\section{Fikry Syarifuddin ${ }^{1}$}

1Fakultas Hukum Universitas Brawijaya Malang, E-mail: Vrahantan@gmail.com

\begin{tabular}{l}
\hline Info Artikel \\
\hline Masuk : 20 Oktober 2020 \\
Diterima : 11 Desember 2021 \\
Terbit : 28 Desember 2021 \\
Keywords: \\
Political family, \\
Constitutionality, regional \\
election. \\
\\
Kata kunci: \\
Politik Kekeluargaan, \\
Konstitusionalitas, Pilkada; \\
Corresponding Author: \\
M. Fikry Syarifuddin, \\
E-mail: vrahantan@gmail.com \\
DOI: \\
10.24843/KP.2021.v43.i03.p05
\end{tabular}

\begin{abstract}
The study aimed to examine the constitutionality of a political family (political dynasty) in the simultaneous regional elections. This research was conducted using doctrinal or normative legal methods. Normative research is carried out by using statutory and legal doctrine approaches in order to study and analyze statutory regulations or other legal materials related to kinship political participation in regional elections. The results of this study indicated that the high participation rate of incumbent families in regional elections has resulted in a decline in the quality of democracy at the regional level. Thus, the political dynasty should be limited through regulations in order to create a healthy and fair democratic process in regional elections.

Abstrak

Penelitian ini bertujuan untuk mengkaji konstitusionalitas politik kekeluargaan (politik dinasti) dalam pemilihan umum kepala daerah (Pemilukada) serentak. Penelitian ini dilakukan dengan menggunakan metode penelitian hukum doktrinal atau normatif. Penelitian normatifini dilakukan dengan menggunakan pendekatan perundangundangan dan doktrin hukum guna mengkaji dan menganalisis peraturan perundang-undangan ataupun bahan hukum lain yang berkaitan dengan partisipasi politik kekeluargaan di dalam pemilukada. Hasil dari penelitian ini menunjukan tingginya angka partisipasi keluarga petahana dalam pemilukada mengakibatkan menurunnya kualitas demokrasi di tingkat daerah. Oleh karena itu, politik kekeluargaan seharusnya dibatasi dengan menggunakan regulasi guna menciptakan proses demokrasi yang fair dan sehat dalam pemilihan kepala daerah.
\end{abstract}

\section{Pendahuluan}

Dinamika ketatanegaraan paska reformasi banyak dihadapkan berbagai tantangan baru, salah satunya adalah kehadiran politik kekeluargaan ${ }^{1}$ di tingkat daerah. Harapan akan

1 Dalam beberapa literatur, banyak istilah yang digunakan, mulai dari "Dinasti Politik", yang dominan digunakan dalam literatur politik, dimana makna itu hampir serupa dengan "Politik kekerabatan". Dalam istilah hukum pernah dijumpai definisi dari dinasti politik dalam Pasal 7 huruf $\mathrm{r}$ yang selanjutnya dijelaskan dalam bab penjelasan bahwasanya: Yang dimaksud 
kehadiran demokrasi di tingkat lokal, terganjal oleh kehadiran politik kekeluargaan yang memonopoli jabatan politik. ${ }^{2}$ Sirkulasi elit kian terganggu, dan publik dihadapkan pada pilihan yang disadurkan oleh keluarga yang sebelumnya memonopoli kekuasaan di tingkat daerah. Itu adalah satu tantangan dari babak baru dalam sistem bernegara di Indonesia. ${ }^{3}$

Pasca Reformasi kita memasuki babak baru dalam sistem bernegara, Adanya amandemen pada konstitusi yang kemudian menjadi landasan baru untuk negara dijalankan secara demokratis dan menjunjung pemenuhan atas hak asasi manusia (HAM). Dengan adanya penegasan secara konstitusional terhadap kedaulatan hukum maka secara De Jure Indonesia merupakan negara yang berdasarkan hukum sebagimana amanat dari pasal 1 (3) UUD 1945. Konsep negara hukum sendiri sudah berkembang sejak lama, namun menurut pandangan dari Philipus M.H baru mulai mendapatkan perhatian di negara-negara Eropa yakni pada Abad ke 19, meski pemikiran tentang negara hukum telah lama ada. ${ }^{4}$

Konsep Negara hukum untuk pertama kalinya disampaikan oleh Plato dan kemudian pemikiran tersebut dipertegas oleh Aristoteles. ${ }^{5}$ Menurut pandangan Aristoteles, yang memerintah dalam sebuah negara bukanlah sekelompok manusia, melainkan pikiranpikiran yang adil dan bijaksana yang menentukan baik atau buruknya hukum. Dengan ditegaskan di dalam konstitusi bahwasanya Indonesia sebagai negara yang berlandaskan hukum maka negara secara konsekuen harus memastikan bahwa hak setiap warga negara terjamin di dalam konstitusi sebagai mana ciri ciri negara hukum yaitu: 6

a. Hubungan antara rakyat dan penguasa diatur dalam Konstitusi yang tertulis,

b. Adanya pembagian dalam kekuasaan Negara, dan

c. Adanya pengakuan dan jaminan terhadap hak-hak rakyat.

Dalam Negara demokrasi yang berlandaskan hukum, masyarakat mengalami perkembangan yang sangat dinamis, maka dibutuhkan perangkat perundangundangan yang juga dapat mengikuti perkembangan masyarakat.

dengan tidak memiliki konflik kepentingan adalah antara lain, tidak memiliki hubungan darah, ikatan perkawinan dan/atau garis keturunan 1 (satu) tingkat lurus ke atas, ke bawah, ke samping dengan petahana... Dalam artikel ini, penulis memilih untuk menggunakan istilah 'Politik Kekeluargaan", yang hakikatnya tidak jauh berbeda dengan istilah-istilah lainnya, dimana politik kekeluargaan adalah dominasi keluarga tertentu yang memiliki hubungan darah, baik memiliki jarak dekat/jauh, dab keluarga itu memiliki pengaruh besar/mendominasi sirkulasi kekuasaan dan kepemimpinan di tingkat daerah. Definisi ini lebih menekankan aspek keluarga, yang jarang terlihat dalam penggunaan istilah-istilah sebelumnya dalam penyebutannya.

2 Darmansyah, R., Syahrani, S. D., \& Harirah, Z. (2020). Potret Dinasti Politik dalam Pengisian Jabatan Administratif. Journal of Political Issues, 2(1), 34-46.

3 Prayudi, (2016), Penyelenggaraan Pilkada dan Lemahnya Sirkulasi Elit Politik Lokal. Jurnal Kajian Vol. 21 No. 4. 275-296.

4 Hadjon. P. M. (1996) Kedaulatan Rakyat,Negara Hukum dan Hak-hak Asasi Manusi(HAM),Kumpulan Tulisan dalam rangka 70 Tahun Sri Soemantri Martosoewignjo, Jakarta: Media Pratama, h. 72.

5 Huda. Ni'matul. (2005). Negara Hukum, Demokrasi dan Judicial Riview, Yogyakarta: UII Press, h.1.

6 Ibid, h. 9. 
Demokrasi menuntut untuk adanya partisipasi masyarakat yang besar, ${ }^{7}$ dengan demikian maka konstitusi secara ideal harus mampu menjamin, terpenuhinya hak asasi manusia agar partisipasi masyarakat terlindungi dan terakomodir dengan baik. Dalam konsep negara hukum modern perlindungan terhadap Hak Asasi adalah sesuatu yang harus terpenuhi dan dijamin oleh konstitusi, sebab tanpa adanya jaminan dan pemenuhan hak asasi manusia akan maka akan menghilangkan esensi dari negara hukum yang akan berdampak pada tumbuhnya kekuasaan yang absolut dan sentralistik (machstaat). ${ }^{8}$ Untuk menjaga agar negara tetap berada pada jalur yang konstitusinal dan adanya kontrol terhadap kekuasaan, maka lahirlah gagasan kedaulatan hukum yang kemudian memberikan legitimasi kepada setiap warga Negara untuk turut serta dalam pemerintahan 9 .

Pemenuhan terhadap hak warga negara dalam model negara hukum Rechstaat atau Rule of law menjadi sebuah keharusan hal ini selaras dengan ciri negara hukum menurut pandangan Friedrich Julius Stahl:10

a. Adanya perlindungan terhadap Hak Asasi Manusia (HAM)

b. Pembentukan Peradilan Administrasi Negara

c. Dalam menjamin Hak Asasi manusia maka dibutuhkan pemisahan (separation) dan pembagian (distribution) kekuasan, dan

d. Adanya peraturan perundang-undangan sebagai landasan dalam menjalankan pemerintahan

Berangkat dari amanat konstitusi Pasal 28 D Ayat (3) UUD NRI Tahun 1945 yang memberikan perlindungan terhadap pemenuhan hak politik warga negara, rumusan pasal 28 D Ayat (3) terkait hak politik ini kemudian digambarkan oleh Nur widyatani, menurutnya hak politik merupakan hak yang mencakup ${ }^{11}$ :

a. Kesempatan warga negara untuk menduduki jabatan public,

b. Kesempatan yang sama kepada setiap warga negara untuk terlibat di dalam pemerintahan,

c. Setiap warga negara memiliki hak untuk mencalonkan diri dan memilih pemimpin yang diinginkan, dan

d. Setiap warga negara memiliki hak untuk menyampaikan aspirasinya kepada pemerintah secara lisan maupun tulisan.

7 Kusmanto, H. (2014), Partisipasi Masyarakat dalam Demokasi Politik. Jurnal Ilmu Pemerintahan dan Sosial Politik Vol. 2, Nomor 1. 78-90. doi: https://doi.org/10.31289/ jppuma.v2i1.582.

8 Aswandi, B., \& Roisah, K. (2019). Negara Hukum Dan Demokrasi Pancasila Dalam Kaitannya Dengan Hak Asasi Manusia (HAM). Jurnal Pembangunan Hukum Indonesia, 1(1), 128-145.

9 Perlindungan Hak turut serta dalam pemerintahan secara internasioanal mulai diakui ketika lahirnya Deklarasi Universal Hak Asasi Manusia tepatnya dalam artikel 21 Ayat (1), (2), dan (3).

10 Marbun S.F. dan Mahfud MD Moh., (1987), Pokok-pokok Hukum Administrasi Negara, Yogyakarta: Liberty, h. 44.

11 Hadjon P. M., Op.Cit, h. 27 
Dalam proses seleksi kepala daerah di Indonesia, hak memilih dan dipilih dijalankan secara langsung dan demokratis sebagaimana diamanatkan di dalam Pasal 1 Ayat (1) UU Pilkada ${ }^{12}$

Ketentuan pasal ini dengan jelas memberikan definisi bahwa Indonesia menggunakan demokrasi langsung dalam pemilihan kepala daerah, setiap rakyat memiliki hak konstitusional untuk menentukan kepala daerahnya dalam sarana pemilihan kepala daerah. Hal ini tentunya sejalan dengan amanat UUD NRI Tahun 1945 Pasal 18 Ayat (4) Yang menyatakan bahwa setiap kepala daerah dipilih secara langsung dengan cara yang demokratis. Dalam praktik pemilihan kepala daerah di Indonesia pasca reformasi, setiap kepala daerah dipilih secara langsung oleh konstituen, hal ini tentunya sejalan dengan amanat konstitusi yang menginginkan untuk proses pemberian kedaulatan oleh rakyat dilaksanakan dengan cara yang demokratis jujur dan adil.

Secara teoritis demokrasi langsung adalah sistem demokrasi yang setiap warga negaranya yang telah memiliki hak politik wajib dilibatkan oleh negara dalam setiap pembuatan kebijakan maupun pengambilan keputusan. ${ }^{13}$ Adanya konsep Pemilu sebgai sarana untuk warga negara menyampaikan aspirasinya, melegitimasi kedaulatannya sendiri atau diwakilkan kepada individu atau lembaga menunjukan bahwa Indonesia telah secara konsekuen memantapkan dirinya sebagai sebuah negara hukum yang demokratis, sebab dihampir seluruh negara demokrasi pemilu dianggap sebagai simbol demokrasi ${ }^{14}$ Pandangan yang sama juga diutarakan oleh Jimly Asshiddiqie dan M. Ali Safa' at, 15 , menegaskan bahwasanya yang menjadi dasar dari hak Hak politik adalah warga Negara dapat berpartisipasi aktif dalam Pemilu untuk menentukan pilihannya. Pemilu sebagai sarana untuk mendelegasikan kedaulatan rakyat sekaligus sebagai ukuran demokratis sebuah negara maka harus diselenggarakan dengan jujur, adil dan juga bebas dari intervensi dan tekanan kekuasaan.

Rakyat Indonesia dapat menggunakan hak politiknya dalam memilih kepala daerah pada Pemilihan umum kepala daerah (PILKADA) yang diselenggarakan tiap lima tahun sekali hal ini bertujuan untuk mengakomodir hak politik setiap warga negara sebagaimana yang diamanatkan oleh konstitusi dan juga untuk membangun sistem demokrasi yang lebih baik. Guna menciptakan sebuah sistem demokrasi yang terkonsolidasi maka dibutuhkan beberpa kriteria yang harus terpenuhi, dalam hal ini Robert A Dahl memberikan beberapa kriteria yaitu16:

a. Practicaly all adults have the right to vote in the election of ofice,

b. Control over government decisions about policy is constitutionaly vested in electedofficialls,

12 Pasal 1 Ayat (1) UU PIlkada: Pemilihan Gubernur, Bupati, dan Walikota yang selanjutnya disebut Pemilihan adalah pelaksanaan kedaulatan rakyat di Provinsi dan Kabupaten/Kota untuk memilih Gubernur, Bupati, dan Walikota secara langsung dan demokratis.

13 Budijanto, O. W. (2017). Pemenuhan Hak Politik Warga Negara Dalam Proses Pemilihan Kepala Daerah Langsung (Fulfillment Of Citizen Political Right In The Direct Election Of Local Leaders Process). Jurnal Penelitian Hukum De Jure, 16(3), 291-307. DOI: http://dx.doi.org/10.30641/dejure.2016.V16.291-307.

14 Budiardjo M., (2008) Dasar Dasar Ilmu Politik (Edisi Revisi), Jakarta: Gramedia Pustaka Utama, h. 46

15 Asshiddiqie J. dan M. Ali Safa'at, (2006), Teori Hans Kelsen tentang Hukum, cetakan pertama, Jakarta: Sekretariat Jendral dan Kapanitraan Mahkamah Konstitusi RI, Jakarta, 2006. P. 77

16 Dahl R. A, (1982). Dilemma of Pluralist Democracy: Autonomy vs Control, Yale University Press. p. 10-11. 
c. Elected officials are chosen in frequent and fairlly conducted elections in which coercion is comparatively uncommon

d. Practically all adults have the right to run for elective offices in the government, thoughage limts may be higher for holding officce than for the suffrage,

e. To achieve their various rights, including tose listed above, citizens also have a right toform relatively independentassociations or organizations, including independent politicalparti and interest group.

f. Citizen have a right to seek out alternative sources of informationn. Moreover, alternativesources of information exist and are protected bylaw, and

g. Citizen have a right to express themselves without the danger of severe punishment onpolitical matters broadly defined, including criticism of officials, the government, the regime, the socioeconomic order, and the prevailing ideology.

Dalam rangka mewujudkan demokrasi dalam sebuah pemerintahan maka pandangan diatas dapat dipergunakan sebagai acuan yang ideal guna mewujudkan demokrasi dalam sebuah pemerintahan. Pada Tahun 2015 Indonesia menyelenggarakan pilkada serentak periode pertama dan Pilkada Tahun 2020 merupakan periode keempat Pilkada serentak. Pilkada serentak Tahun 2020 tidak mengalami banyak perubahan dari segi keikutsertaan petahana maupun keluarga petahana, hal ini disebabkan karena tidak adanya regulasi yang secara tegas membatasi keikutsertaan keluarga petahana dalam pilkada. Jika melihat data yang dirilis oleh Nagara institute terdapat 124 calon kepala daerah pada pilkada 2020 yang memiliki hubungan kekeluargaan dengan petahana, berikut rinciannya ${ }^{17}$ :

Tabel politik kekeluargaan dalam Pilkada serentak Tahun 2020 di Indonesia

\begin{tabular}{|c|l|c|}
\hline No & \multicolumn{1}{|c|}{ Calon Kepala Daerah } & Jumlah \\
\hline 1 & Calon Bupati & 57 \\
\hline 2 & Calon Wakil Bupati & 30 \\
\hline 3 & Calon Walikota & 20 \\
\hline 4 & Calon Wakil Walikota & 8 \\
\hline 5 & Calon Gubernur & 5 \\
\hline 6 & Calon Wakil Gubernur & 4 \\
\hline & & 124 \\
\hline
\end{tabular}

Dari data riset yang dilakukan Nagara Institute dapat dilihat bahwasanya terdapat 124 calon kepala daerah yang memiliki hubungan kekerabatan dengan petahana ataupun yang maju sebagai petahana dimana 22 diantaranya merupakan petahana dan 102 merupakan pendatang baru. Dari table diatas dapat dilihat bagaimana besarnya sebaran politik kekeluargaan yang ikut serta dalam pilkada serentak Tahun 2020, dengan banyaknya politik kekeluargaan di berbagai daerah maka pilkada seolah hanya menjadi lahan untuk mempertahankan kekuasaan oleh sebagian kelompok/ politik kekeluargaan. Padahal dalam demokrasi yang ideal, masyarakat seharusnya mendapatkan kesempatan yang luas untuk bersaing secara fair dalam kontestasi pilkada.

17 Fadhillah D. N., Ramadhan F., dan Dewa T. T. (2020). Dinasti Politik Dalam Pemilihan Kepala Daerah Tahun 2020, Jakarta: Nagara Institute. 
Undang-undang pilkada sebagai perangkat hukum dalam pelaksanaan seleksi kepala daerah seharusnya memiliki formulasi hukum yang baik guna memastikan bahwa proses kontestasi pilkada dapat terlaksana dengan adil dan demokratis. Pilkada yang baik dan berkualitas hanya dapat tercapai apabila setiap orang ditempatkan dalam posisi yang sama dan setara dalam menggunakan haknya untuk dipilih dan/atau memilih.artinya sangat terbuka ruang partisipasi bagi seluruh masyarakat untuk turut serta berkontestasi dalam agenda lima tahunan ini, sebab terlepas dari hak memilih, masyarakat juga memiliki hak dipilih asalkan mampu memenuhi persyaratan yang diatur dalam undang undang pilkada, sebab setiap orang memiliki kesempatan yang sama untuk menduduki jabatan publik lewat sarana pilkada. ${ }^{18}$ Namun sangat disayangkan dalam praktiknya tidak semua orang memiliki kesempatan yang sama dan setara dalam persaingan untuk menduduki jabatan kepala daerah, hal ini merupakan implikasi dari eksisnya politik kekeluargaan di berbagai daerah di Indonesia. Persoalan politik kekeluargaan sebelumnya sudah diatur di dalam Undang-undang Pilkada ${ }^{19}$ dan kemudian dijelaskan dalam bagian penjelasan Pasal 7 huruf r UU Pilkada. Namun setelah dilakukan uji materil Mahkamah Konstitusi (MK) dalam Putusan No: 33/PUUXIII/2015 berpandangan bahwa pasal tersebut bertentangan dengan konstitusi. ${ }^{20}$ Mahkamah konstitusi tentunya tidak salah jika menghadapkan larangan untuk keluarga petahana dengan pasal 28 Ayat (2) UUD NRI Tahun 1945 yang menyatakan bahwa "Setiap orang bebas dari perlakuan yang bersifat diskriminatif..." 21.

Namun di sisi yang lain keikutsertaan keluarga petahana cenderung mengakibatkan persaingan dalam kontestasi pilkada yang tidak setara atau dalam kata lain tidak sesuai dengan amanat konstitusi dengan demikian maka pembatasan keikutsertaan keluarga petahana adalah sesuatu ideal guna menjamin Pilkada dapat terselenggara dengan adil dan memberikan kesempatan yang sama untuk setiap warga negara yang ikut serta mencalonkan diri sebagai kepala daerah, pembatasan keikutseraan keluarga petahana juga dimaksudkan untuk meminimalisir ekses negatif otonomi daerah yang selama ini melahirkan politik kekeluargaan di tiap daerah.

Atas beberapa penjabaran diatas, maka negara dalam hal ini memiliki kewajiban dan tanggung jawab untuk memberikan kesempatan yang seluas luasnya untuk setiap warga negara dapat mencalonkan diri sebagai kepala daerah dan menjamin proses demokrasi di tingkat daerah berjalan secara fair. Rumusan masalah dalam penelitian ini adalah bagaimana konstitusionalitas politik kekeluargaan dalam pilkada serentak Tahun 2020?

\section{Metode Penelitian}

Penulisan jurnal ini menggunakan penelitian doktrinal atau normatif yaitu penelitian yang meletakkan hukum sebagai sebuah bangunan sistem norma, yang terdiri dari asas asas, norma, kaidah dari peraturan perundangan, putusan pengadilan, perjanjian serta

18 Hanafi, R. I. (2016). Pemilihan Langsung Kepala Daerah di Indonesia: Beberapa Catatan Kritis Untuk Partai Politik. Jurnal penelitian politik, 11(2), 1-16.

19 Lihat Prasyarat Calon Kepala Daerah yang tercantum dalam Pasal 7 Huruf $r$ Undang Undang Nomor 1 Tahun 2015 Tentang Pemilihan kepala daerah.

20 Lihat Putusan Mahkamah Konstitusi Nomor 33/PUU-XIII/2015 pada halaman 160.

21 Lihat Pasal 28I Ayat (2) Undang Undang Dasar Negara Republik Indonesia Tahun 1945 
doktrin (ajaran).22 Sedangkan dikatakan juga sebagai penelitian kepustakaan ataupun study dokumen dikarenakan penelitian ini lebih banyak dilakukan dengan data yang bersifat sekunder yang tersedia di Perpustakaan ${ }^{23}$. Dalam penulisan jurnal ini penulis juga menggunakan beberapa pendekatan yakni pendekatan perundang undangan, konseptual maupun pendekatan kasus. Teknik analisis data yang digunakan dalam penelitian ini adalah deskriptif, yakni menguraikan dan mendeskripsi setiap data yang diperoleh dari bahan hukum dalam penelitian ini.

\section{Hasil Dan Pembahasan}

Secara sederhana demokrasi langsung adalah sebuah sistem demokrasi yang semua warga negara dapat aktif terlibat di dalam pembuatan keputusan-keputusan atau kebijakan-kebijakan yang dihasilkan oleh negara, mereka tidak mewakilkan pandangan atau pikiran, atau kepentingan mereka pada orang lain yang mengatasnamakan mereka (legislatif). ${ }^{24}$ Demokrasi merupakan tatanan hidup bernegara yang menjadi pilihan negara-negara di dunia pada umumnya dan Pemilihan langsung dimaksudkan untuk mengakomodir hak politik rakyat untuk dipilih dan memilih, juga sebagai sarana yang legal untuk rakyat dapat menyalurkan aspirasinya lewat pemilihan umum hal ini merupakan penegasan dari adanya pengakuan dan jaminan terhadap hak kebebasan setiap warga negara ${ }^{25}$.

Demokrasi tentunya lahir dari tuntutan masyarakat untuk menciptakan persamaan hak dan kedudukan yang sama di depan hukum. Berkaca pada apa yang terjadi di dunia barat sebelum adanya deklarasi Amerika dan France, tatanan masyarakat barat sudah mendorong untuk adanya sebuah sistem demokrasi hal ini dikarenakan persoalan rasisme dan diskriminasi yang menyebabkan Negara tidak menempatkan setiap orang pada posisi yang setara. Menurut M. Solly Lubis, ${ }^{26}$ demokrasi langsung atau demokrasi partisipatif adalah sebuah sistem yang pengambilan keputusan terkait permasalahan umum dapat melibatkan rakyat secara langsung. Sebab dapat kita lihat dalam praktek bernegara sebelum masuk pada era reformasi, demokrasi yang memposisikan rakyat dalam penentuan kebijakan negara, seringkali bergeser ketika peranan negara yang terwujud dalam pemerintahan melakukan berbagai pembatasan terhadap pertisipasi masyarakat dalam negara maupun menempatkan posisi warga negara secara proporsional di hadapan hukum dan pemerintahan.

Smith, Dahl, maupun Mawhood mengatakan bahwa guna mewujudkan local accountabillity, pollitical equity, and local responsivenness, yang merupakan tujuan dari desentralisasi, maka pemerintah daerah dalam hal ini diharuskan:

a. Memiliki pendapatan asli daerah sendiri,

b. Adanya pengawasan dari parlemen daerah kepada lembaga eksekutif di daerah,

c. Adanya wilayah administrasi dan

22 Sonata, D. L. (2014). Metode Penelitian Hukum Normatif dan Empiris: Karakteristik Khas dari Metode Meneliti Hukum. Fiat Justisia Jurnal Ilmu Hukum, 8(1), 15-35. h. 25. DOI: https://doi.org/10.25041/fiatjustisia.v8no1.283.

23 Suratman dan Dillah P., (2013) Metode Penelitian Hukum, Bandung: Alfabeta, h. 51.

24 Patta, A. K. (2009). Masalah dan Prospek Demokrasi. Jurnal Academica, 1(1). 35-43.

25 Pratikno, (2005) "Demokrasi dalam Pilkada Langsung",Makalah, Sarasehan Menyongsong Pilkada Langsung,IRCOS-FNSt, Hotel Saphir.

26 Lubis M. S. (1998), Ilmu Negara, Cetakan ketiga, Bandung: Mandar Maju, h. 66 
d. Adanya pemilihan umum sebagai sarana untuk memilih kepala daerah ${ }^{27}$.

Guna mengakomodir aspirasi rakyat di tingkat Daerah, dan membangun sarana untuk kedaulatan rakyat di tingkat Daerah maka Pemilihan Umum di tingkat Daerah dijalankan dengan mekanisme pilkada sebagaimana diamanatkan oleh konstitusi, ${ }^{28}$ yang kemudian tata laksananya diatur lebih lanjut di dalam Undang -Undang Pilkada. Sejak tahun 2015 Pilkada dilaksanakan secara serentak di beberapa daerah di Indonesia, mekanisme pilkada serentak ini berdasarkan amanat dari Pasal 201 Ayat (1) hingga Ayat (12) Undang Undang Pilkada. Mekanisme Pemilihan Umum serentak tentunya akan memberikan dampak yang besar dalam proses demokrasi di indonesia. Namun pertanyaan ontologis yang selalu muncul jika melihat kualitas Pilkada yakni apakah pemilihan kepala daerah sudah berjalan sesuai dengan rambu rambu demokrasi sebagaimana yang diamanatkan oleh konstitusi? Ataukah justru menjadi sarana untuk oligarki politik membangun raja-raja kecil di tiap tiap daerah?. Untuk menjawab pertanyaan ini tentunya data yang dipaparkan oleh Nagara Institut bahwasanya dalam Pilkada serentak Tahun 2020 terdapat 124 calon kepala daerah yang memiliki hubungan kekeluargaan dengan petahana. Hal ini tentunya sangat jauh dari asas demokrasi yang menempatkan seseorang pada posisi yang fair dan setara dalam kontestasi menduduki jabatan publik, realitas ketidakadilan ini sering kita temui juga dalam penegakan hukum yang tidak secara konsekuen menjalankan asas demokrasi hukum equality before the law. Dalam beberapa persoalan hukum terlihat sangat powerfull namun saat berhadapan dengan orang yang memiliki kekuasaan ataupun relasi dengan kekuasan hukum sering kali tak berdaya atau terlihat mandul yang sering diibaratkan seperti pisau yang tajam kebawah namun tumpul keatas. ${ }^{29}$

Tingginya angka politik kekeluargaan dalam pilkada 2020 menunjukan bahwa demokrasi tidak berjalan sesuai dengan amanat konstitusi yakni mampu menjamin hak setiap orang terlindung dan terpenuhi, juga membatasi hak setiap individu untuk memastikan hak individu lain dapat terpenuhi. Suburnya praktek politik kekeluargaan dalam demokrasi lokal seharusnya menjadi landasan lembaga pembuat peraturan perundang-undangan (legislatif) untuk memformulasikan regulasi guna menyelesaikan persoalan politik kekeluargaan dalam tubuh demokrasi dan memastikan demokrasi berjalan sesuai dengan amanat konstitusi. Demokrasi seharusnya membuka kesempatan bagi setiap warga negara agar dapat mengisi jabatan publik melalui cara cara yang konstitusional, hal ini juga selaras dengan pandangan Marcus Mietzner ${ }^{30}$ yang menurutnya praktik politik kekeluargaan berkembang subur dalam sistem demokrasi di Indonesia. Eksisnya politik kekeluargaan dalam sistem demokrasi menurut Mietzner tidak sehat bagi pertumbuhan demokrasi, sebab dapat melemahkan kontroling terhadap kekuasaan (chek and balance), tidak adanya kontrol terhadap kekuasaan itu

27 Hidayat, S. (2000), Refleksi Realitas Otonomi Daerah dan Tantangan Masa Depan, Jakarta: Pustaka Quantum, h. 19

28 Lihat Pasal 18 Ayat (4) UUD NRI Tahun 1945 “Gubernur, Bupati, dan Walikota masingmasing sebagai kepala pemerintahan daerah provinsi, kabupaten, dan kota dipilih secara demokratis"

29 Sutisna, A. (2017). Gejala proliferasi dinasti politik di Banten era kepemimpinan gubernur Ratu Atut Chosiyah. Politik Indonesia: Indonesian Political Science Review, 2(2), 100-120. DOI: https://doi.org/10.15294/jpi.v2i2.9329.

30 Mietzner, M. (2009). Indonesia's 2009 elections: populism, dynasties and the consolidation of the party system. Sidney: Lowy Institute For International Policy. 
sendiri dapat menyebabkan demokrasi berubah menjadi otoriter dengan kekuasaan yang absolut tanpa pengawasan. ${ }^{31}$

Dalam dunia politik modern praktek politik kekeluargaan lebih dikenal sebagai aktor atau petinggi politik yang memiliki basis pertalian darah atau hubungan kekerabatan, inilah yang kemudian dikatakan sebagai oligarki politik oleh para pengamat demokrasi dan politik. Fenomena menguatnya jaringan politik yang dibangun dengan dasar kedekatan politik keluarga menyebabkan tertutupnya rekrutmen politik yang fair bagi orang-orang yang berada di luar politik kekeluargaan. Menguatnya praktik politik kekeluargaan dalam setiap kontestasi pilkada seharunya dijadikan sebagai landasan atau pertimbangan oleh Mahkamah Konstitusi ketika melakukan yudicial review terhadap konstitusionalitas pasal 7 Huruf $\mathrm{r}$ Undang-undang Pemilihan kepala daerah. Dengan adanya pasal yang membatasi keikutsertaan keluarga petahana dalam pilkada tentu dimaksudkan untuk menciptakan kontestasi demokrasi yang sehat dan fair sesuai dengan konsep Negara hokum yang demokoratis.

Mahkamah konstiusi dalam fungsinya sebagai The Guardian Of Constitution yang memiliki kewenangan untuk menjaga konstitusionalitas demokrasi seharusnya mampu membuat putusan yang memberikan dampak positif pada keberlangsungan demokrasi. ${ }^{32}$ Bambang Widjojanto memberikan beberapa syarat untuk menciptakan pilkada yang berkualitas yakni tergantung pada:33 pertama, kualitas proses pemilu, yakni tergantung bagaimana legitimasi dan independensi penyelenggara dapat dijamin, serta rendahnya konflik yang ditimbulkan. Kedua kualitas hasil pemilu, hal ini menitikberatkan pada kualitas pemenang pemilu itu sendiri Ketiga, kualitas administratif dalam proses pemilihan umum, yakni tergantung pada kesiapan regulasi, tata cara pelaksana, anggaran, dan daftar pemilih.

Ukuran kualitas pemilihan kepala daerah tersebut dapat dicapai dengan beberapa syarat, salah satunya yakni tersedianya regulasi pilkada yang mampu menjamin pilkada berjalan secara demokratis (electoral laws) dan pelaksanaan pilkada yang demokratis (electoral process) oleh lembaga penyelenggara pilkada. ${ }^{34}$ Melihat realitas politik hari ini, akan sangat sulit untuk menciptakan pilkada yang demokratis dan bebas dari anasir politik kekeluargaan, hal ini sangat jauh dari semangat konstitusi untuk mereformasi sistem seleksi pejabat publik. Rezim baru pemerintahan daerah, menuntut agar pemilihan kepala daerah secara langsung hal ini bertujuan untuk: 35

a. Memberikan kesempatan kepada masyarakat untuk memilih sendiri kepala daerah yang dirasa mampu mewakili kepentingannya, dan jika kepala daerah setelah

31 Faharudin, F. (2017). Prinsip Checks And Balances Ditinjau dari Sisi dan Praktik. Jurnal Hukum Volkgeist, 1(2), 115-128. doi: https:/ / doi.org/10.35326/volkgeist.v1i2.97.

32 Sa'adah, N. (2019). Mahkamah Konstitusi Sebagai Pengawal Demokrasi Dan Konstitusi Khususnya Dalam Menjalankan Constitutional Review. Administrative Law and Governance Journal, 2(2), 235-247. DOI: https://doi.org/10.14710/alj.v2i2.235-247.

33 Pratikno, Op.Cit. h. 6

34 Pahlevi, I. (2016). Lembaga penyelenggara pemilihan umum di indonesia: berbagai permasalahannya. Jurnal Politica Dinamika Masalah Politik Dalam Negeri dan Hubungan Internasional, 2(1). 45-72. doi: 10.22212/jp.v2i1.286

35 Widjojanto B., (2003), Pemilihan Langsung Kepala Daerah : Upaya Mendorong Proses Demokratisasi, Makalah pada seminar nasional Pemilihan Langsung Kepala daerah sebagai Wujud Demokrasi Lokal, Adeksi. h. 11 
menjabat dirasa tidak mewakili suara konstituen maka masyarakat dapat untuk tidak memilihnya kembali dalam pilkada selanjutnya,

b. Masyarakat dapat memilih kepala daerah yang visi misinya dirasa sejalan dengan kepentingan masyarakat dan tidak memiliki beban politik yang berlebihan kepada partai politik pengusung.

c. Pemilihan secara langsung oleh konstituen dapat memberikan tanggungjawab yang lebih kepada kepala daerah terpilih untuk bekerja demi kesejahteraan dan kepentingan konstituen.

Pandangan diatas semakin menegaskan mengapa politik kekeluargaan sangat bertendensi merusak jalannya demokrasi. Politik Kekeluargaan di Indonesia bukan lagi persoalan baru, model politik semacam ini tumbuh subur pada era orde baru bahkan tidak sempat diamputasi saat memasuki era reformasi, politik kekeluargaan pada era reformasi dapat ditemui hampir di tiap daerah di Indonesia. ${ }^{36}$ Berdasarkan opini Ikrar Nusa Bakti yang ditulis dalam kolom opini Seputar Indonesia tertanggal 1 Juni Tahun 2010 yang berjudul berjudul "Polemik Istri Pejabat Maju Pilkada" dia mengemukakan faktor-faktor yang menyebabkan munculnya fenomena istri bupati salah satunya yakni untuk tetap dapat mempertahankan kekuasaan dan juga mengakumulasi kekayaan. Fenomena kepala daerah yang selesai periode dan digantikan oleh Istri, anak, atau suaminya merupakan rangkaian kasus politik kekeluargaan yang menunjukan bahwa kekuasaan seringkali hanya dikuasai dan diduduki oleh sebagian orang yang masih memiliki hubungan keluarga. Demokrasi ditingkat lokal idealnya merupakan sarana konstitusional untuk mewujudkan local good governance yang menurut pandangan Goran Hayden, ${ }^{37}$ ditunjang oleh dimensi aktor. Pada dimensi aktor pilkada hendak menekankan pentingnya kekuasaan, kewenangan, respiratory antara rakyat dan pemimpin serta pergantian kekuasaan.

Pembiaran dan legitimasi terhadap keikutsertaan keluarga petahana dalam pilkada merupakan sebuah praktek demokrasi yang jauh dari esensi dan tujuan yang ingin dicapai oleh demokrasi, sebab pilkda lahir dari tuntutan reformasi untuk memutuskan rantai kekuasaan yang bersifat sentralistik dan absolut. Meningkatnya angka politik kekeluargaan di tingkat lokal sama seperti memindahkan kekuasaan yang tadinya tersentralistik di pusat ke daerah, sebab kekuasaan hanya dipegang oleh segelintir aktor politk dan keluarganya. Hal ini tentu merupakan penyebab terciptanya iklim pilkada yang tidak fair dan jauh dari kata demokrasi yang konstitusional sebab hak dipilih tidak diletakkan pada posisi yang equal dan fair.

Pada tahun 2015 para pembuat regulasi sudah memberikan perhatian untuk menyoroti fenomena politik kekeluargaan yang terjadi di tingkat lokal, dengan diberikan limitasi terkait keikutsertaan keluarga petahana dalam pilkada sebagaimana yang ditegaskan dalam pasal 7 huruf r UU No 8/2015 Tentang Pilkada yang menyatakan bahwa calon kepala daerah tidak memiliki konflik kepentingan dengan petahana, adanya limitasi yang dibuat oleh lembaga legislatif dimaksudkan untuk menciptakan demokrasi yang konstitusional yang menempatkan setiap calon kepala daerah pada posisi yang setara guna menciptakan local good governance. Namun pasal ini tidak bertahan lama sebab

36 Agustino, L. (2010). Dinasti Politik Pasca-Otonomi Orde Baru: Pengalaman Banten dalam. Majalah Prisma, Otonomi Daerah Untuk Siapa, 29(3), 109.

37 Hyden, G. (1992). The study of Governance. Governance and Politics in Africa (Lynner Rienner Boulder, Col 1992), 1-26. 
pada tahun 2015 ada permohonan untuk uji materil Pasal 7 Huruf $r$ Undang undangPilkada, dan dalam Amar putusan Mahkamah Konstitusi Nomor 33/PUU-XII/2015 Mahkamah Konstitusi mengabulkan permohonan pemohon dan pasal ini dinyatakan inkonstitusional.

Mahkamah berpendapat bahwa limitasi terhadap keikutsertaan keluarga petahan merupakan materi undang undang yang diskriminatif dan bertentangan dengan konstitusi. Dengan adanya Putusan Mahkamah Konstitusi No. 33/PUU-XIII/2015 Penulis menilai bahwasanya mahkamah konstitusi secara tidak langsung turut melegitimasi politik kekeluargaan yang selalu eksis dalam setip perhelatan pemilihan kepala daerah. Praktik politik kekeluargaan dalam Pilkada 2020 tentunya secara siluet dapat kita lihat sebagai bentuk dari dinastokrasi (dynast-ocracy) yang menghilangkan esensi dari konsep demokrasi sebgaimana yang digambarkan dalam buku Oligarchy milik Jeffrey A. Winters, bahwa oligarki merupakan individu ataupun kelompok yang bertumpu pada kekuatan sumber daya material sebagai basis dan upaya pertahanan diri mereka. ${ }^{38}$

Menanggapi Putusan Mahkamah Konstitusi No. 33/PUU-XIII/2015 dan mengaitkannya dengan politik kekeluargaan dalam pilkada serentak yang berlangsung pada desember 2020 maka dapat dilihat bahwasanya pertimbangan putusan Mahkamah Konstitusi (ratio decidendi $M k$ ) terlalu formalistik sehingga mengesampingkan aspekaspek substantif dalam demokrasi, hal ini sama seperti mahkamah konstitusi memberikan angin segar kepada oligarki untuk membangun politik kekeluargaan di tiap-tiap daerah.

\section{Kesimpulan}

Demokrasi yang diharapkan paska reformasi adalah demokrasi yang terlaksana dalam seluruh lini kehidupan pemerintah, mulai dari tingkap pusat hingga lokal. Akan tetapi harapan terlaksananya demokrasi substansial yang memiliki sirkulasi kekuasaan yang sehat, dihadapkan dengan tantangan serius, yang salah satunya munculnya fenomena politik kekeluargaan. Undang Undang Pilkada sudah mengantisipasi serta merespon fenomena tersebut, sayangnya melalui Mahkamah Konstitusi keberadaan norma pasal 7 huruf $r$ Undang Undang Pilkada dibatalkan. Ratio Decindendi Mahkamah Konstitusi dalam amar putusan nomor No. 33/PUU-XIII/2015 yang melihat limitasi keikutsertaan keluarga petahana dalam muatan materi Pasal 7 huruf $r$ Undang undang Pilkada sebagai bentuk diskriminatif merupakan sebuah pertimbangan yang antinomi sebab pada sisi yang lain limitasi tersebut dibutuhkan untuk menciptakan demokrasi lokal yang lebih adil. Demokrasi harus memberikan posisi yang setara bagi tiap peserta yang ingin menduduki jabatan publik dan berkontestasi dalam proses seleksi untuk menduduki kepala daerah. Kesetaraan pasangan calon kepala daerah dalam memulai kontestasi adalah syarat yang penting, seperti konsep fairness yang ditegaskan oleh John Rawls dalam Theory of Justice. Sehingga implikasi yuridis dari putusan Mahkamah konstitusi tersebut berdampak pada tidak sehatnya persaingan untuk mengisi jabatan publik di tingkat lokal. Berdasarkan pada pembahasan di simpulan tersebut, penulis memberikan rekomendasi di masa mendatang, perlu adanya pembatasan atau limitasi terkait keikutsertaan keluarga petahana dalam kontestasi pilkada, setidaknya limitasi

38 Winters J.A., (2011). Oligarki. Jakarta: Gramedia Pustaka Utama. h.11. 
tersebut bertujuan untuk menciptakan demokrasi local yang berkualitas dan meminimalisir dominasi politik kekeluargaan di daerah.

\section{Daftar Pustaka / Daftar Referensi}

\section{Buku}

Asshiddiqie J. dan M. Ali Safa'at, (2006), Teori Hans Kelsen tentang Hukum, cetakan pertama, Jakarta: Sekretariat Jendral dan Kapanitraan Mahkamah Konstitusi RI.

Budiardjo M., (2008) Dasar Dasar Ilmu Politik (Edisi Revisi), Jakarta: Gramedia Pustaka Utama.

Dahl R. A, (1982). Dilemma of Pluralist Democracy: Autonomy vs Control, Yale University Press.

Hadjon. P. M. (1996) Kedaulatan Rakyat,Negara Hukum dan Hak-hak Asasi Manusi(HAM), Kumpulan Tulisan dalam rangka 70 Tahun Sri Soemantri Martosoewignjo, Jakarta: Media Pratama.

Hidayat S. (2000). Refleksi Realitas Otonomi Daerah dan Tantangan Masa Depan. Jakarta: Penerbit Pustaka Quantum.

Huda. Ni'matul. (2005). Negara Hukum, Demokrasi dan Judicial Riview, Yogyakarta: UII Press.

Lubis M. S. (1998). Ilmu Negara, cetakan ketiga. Bandung: Penerbit mandar maju.

Marbun S.F. dan Mahfud MD Moh., (1987), Pokok-pokok Hukum Administrasi Negara, Yogyakarta: Liberty.

Mietzner, M. (2009). Indonesia's 2009 elections: populism, dynasties and the consolidation of the party system. Sidney: Lowy Institute For International Policy.

Suratman dan Dillah P. (2013). Metode Penelitian Hukum, Bandung: Penerbit Alfabeta.

Winters J.A., (2011). Oligarki. Jakarta: Gramedia Pustaka Utama.

\section{Jurnal}

Agustino, L. (2010). Dinasti Politik Pasca-Otonomi Orde Baru: Pengalaman Banten dalam. Majalah Prisma, Otonomi Daerah Untuk Siapa, 29(3), 109.

Aswandi, B., \& Roisah, K. (2019). Negara Hukum Dan Demokrasi Pancasila Dalam Kaitannya Dengan Hak Asasi Manusia (HAM). Jurnal Pembangunan Hukum Indonesia, 1(1), 128-145.

Budijanto, O. W. (2017). Pemenuhan Hak Politik Warga Negara Dalam Proses Pemilihan Kepala Daerah Langsung (Fulfillment Of Citizen Political Right In The Direct Election Of Local Leaders Process). Jurnal Penelitian Hukum De Jure, 16(3), 291307. DOI: http://dx.doi.org/10.30641/dejure.2016.V16.291-307.

Darmansyah, R., Syahrani, S. D., \& Harirah, Z. (2020). Potret Dinasti Politik dalam

Pengisian Jabatan Administratif. Journal of Political Issues, 2(1), 34-46. 
Fadhillah D. N., Ramadhan F., dan Dewa T. T. (2020). Dinasti Politik Dalam Pemilihan Kepala Daerah Tahun 2020, Jakarta: Nagara Institute.

Faharudin, F. (2017). Prinsip Checks And Balances Ditinjau dari Sisi dan Praktik. Jurnal Hukum Volkgeist, 1(2), 115-128. doi: https://doi.org/10.35326/ volkgeist.v1i2.97.

Hanafi, R. I. (2016). Pemilihan Langsung Kepala Daerah di Indonesia: Beberapa Catatan Kritis Untuk Partai Politik. Jurnal penelitian politik, 11(2), 1-16.

Hyden, G. (1992). The study of Governance. Governance and Politics in Africa (Lynner Rienner Boulder, Col 1992), 1-26.

Kusmanto, H. (2014), Partisipasi Masyarakat dalam Demokasi Politik. Jurnal Ilmu Pemerintahan dan Sosial Politik Vol. 2, Nomor 1, p. 78-90. doi: https://doi.org/10.31289/jppuma.v2i1.582.

Pahlevi, I. (2016). Lembaga penyelenggara pemilihan umum di indonesia: berbagai permasalahannya. Jurnal Politica Dinamika Masalah Politik Dalam Negeri dan Hubungan Internasional, 2(1). 45-72. doi: 10.22212/jp.v2i1.286.

Patta, A. K. (2009). Masalah dan Prospek Demokrasi. Jurnal Academica, 1(1). 35-43.

Prayudi, (2016), Penyelenggaraan Pilkada dan Lemahnya Sirkulasi Elit Politik Lokal. Jurnal Kajian Vol. 21 No. 4. 275-296.

Pratikno. (2005) Demokrasi dalam Pilkada Langsung. Makalah, Sarasehan Menyongsong Pilkada Langsung,IRCOS-FNSt, Hotel Saphir,Yogyakarta.

Sa'adah, N. (2019). Mahkamah Konstitusi Sebagai Pengawal Demokrasi Dan Konstitusi Khususnya Dalam Menjalankan Constitutional Review. Administrative Law and Governance Journal, 2(2), 235-247. DOI: https://doi.org/10.14710/alj.v2i2.235247.

Sonata, D. L. (2014). Metode Penelitian Hukum Normatif dan Empiris: Karakteristik Khas dari Metode Meneliti Hukum. Fiat Justisia Jurnal Ilmu Hukum, 8(1), 15-35. h. 25. DOI: https://doi.org/10.25041/fiatjustisia.v8no1.283.

Sutisna, A. (2017). Gejala proliferasi dinasti politik di Banten era kepemimpinan gubernur Ratu Atut Chosiyah. Politik Indonesia: Indonesian Political Science Review, 2(2), 100-120. DOI: https://doi.org/10.15294/jpi.v2i2.9329.

Widjojanto B., (2003), Pemilihan Langsung Kepala Daerah : Upaya Mendorong Proses Demokratisasi, Makalah pada seminar nasional Pemilihan Langsung Kepala daerah sebagai Wujud Demokrasi Lokal, Adeksi.

\section{Perundang-undangan}

Undang-Undang Dasar Negara Republik Indonesia Tahun 1945

Nomor 10 Tahun 2016 Tentang Pemilihan Gubernur,Bupati,dan Walikota.

Putusan Mahkamah Konstitusi Nomor 33/ PUU-XIII/2015

Deklarasi Universal Hak Asasi Manusia (DUHAM) 